\title{
ÖGUM Förderpreis
}

Der ÖGUM-Vorstand möchte wieder einmal darauf hinweisen, daß ein attraktiver Förderpreis für den Sonografie-Nachwuchs zur Verfügung steht. Einreichungen von interessanten Projektideen oder Pilotstudien können jederzeit von jüngeren Mitgliedern vorgenommen werden und sind sehr willkommen! Weitere Details entnehmen Sie bitte den Förderpreisstatuten auf der Internetseite: http://www.oegum.at/ausbildung/ foerderpreisstatuten.html

Wir freuen uns auf die Zusendung Ihrer interessanten Sonografie-Projektvorschläge !

CKollmann 